Article

\title{
Comparison of the Effect of Fertilization with Ash from Wood Chips on Bacterial Community in Podzolic and Chernozem Soils for the Cultivation of Winter Oilseed Rape: A Preliminary Study
} Jadwiga Stanek-Tarkowska ${ }^{1, *} \mathbb{1}$, Miłosz Pastuszczak ${ }^{1}$, Ewa Szpunar-Krok ${ }^{2} \mathbb{1}$, Miroslava Kačániová
Maciej Ireneusz Kluz ${ }^{3}{ }^{3}$, Ewa Antonina Czyż ${ }^{1}$, Rafał Pieniążek $^{1}$, Karol Skrobacz $^{1}$ and Karol Pietrzyk ${ }^{3}$

1 Department of Soil Science, Environmental Chemistry and Hydrology, University of Rzeszow, Zelwerowicza 8B, 35-601 Rzeszów, Poland; miloszp@dokt.ur.edu.pl (M.P.); eczyz@ur.edu.pl (E.A.C.); rpieniazek@ur.edu.pl (R.P.); kskrobacz@ur.edu.pl (K.S.)

2 Department of Plant Production, College of Natural Sciences, University of Rzeszów, Zelwerowicza 4, 35-601 Rzeszów, Poland; eszpunar@ur.edu.pl

3 Department of Bioenergetics, Food Analysis and Microbiology, Institute of Food and Nutrition Technology, University of Rzeszow, 35-959 Rzeszow, Poland; mkacaniova@ur.edu.pl (M.K.); mkluz@ur.edu.pl (M.I.K.); karolp@dokt.ur.edu.pl (K.P.)

4 Institute of Horticulture, Faculty of Horticulture and Landscape Engineering, Slovak University of Agriculture, Tr. A. Hlinku 2, 94976 Nitra, Slovakia

check for updates

Citation: Stanek-Tarkowska, J.; Pastuszczak, M.; Szpunar-Krok, E.; Kačániová, M.; Kluz, M.I.; Czyż, E.A.; Pieniążek, R.; Skrobacz, K.; Pietrzyk, K. Comparison of the Effect of Fertilization with Ash from Wood Chips on Bacterial Community in Podzolic and Chernozem Soils for the Cultivation of Winter Oilseed Rape: A Preliminary Study. Agronomy 2022, 12, 576. https://doi.org/10.3390/ agronomy12030576

Academic Editor: Carmelo Maucieri

Received: 30 January 2022

Accepted: 24 February 2022

Published: 25 February 2022

Publisher's Note: MDPI stays neutral with regard to jurisdictional claims in published maps and institutional affiliations.

Copyright: (C) 2022 by the authors. Licensee MDPI, Basel, Switzerland. This article is an open access article distributed under the terms and conditions of the Creative Commons Attribution (CC BY) license (https:// creativecommons.org/licenses/by/ $4.0 /)$.

* Correspondence: jstanek@ur.edu.pl

\begin{abstract}
The aim of the research was to investigate whether different doses of ash from biomass combustion (Salix viminalis L. willow) have an impact on the number and community of soil bacteria. The experiment was carried out on podzolic and chernozem soils in a one-way field experiment (control, NPK, 100, 200, 300, 400, $500 \mathrm{~kg} \mathrm{~K}_{2} \mathrm{Oha}^{-1}$ ). The ash from the biomass was characterized by $\mathrm{pH} 12.83 \pm 0.68$ and high content of macronutrients. Samples were taken from the $0-5 \mathrm{~cm}$ layer of soil under the cultivation of winter oilseed rape (Brassica napus L. var. Napus) in April and September 2021. The plate count method with PCA solid medium was used to determine the number of microorganisms, and mass spectrometry (MALDI-TOF MS) was used to analyze the microbiological community. The research showed an increase in the number of microorganisms after the use of the biomass ash fertilizer in the variants with ash doses from 200 to $500 \mathrm{~kg} \mathrm{~K}_{2} \mathrm{Oha}^{-1}$. The highest amount of soil bacteria in both tested soils was determined in these variants. In total, 44 bacterial species of 5 genera were identified in all variants: Bacillus, Paenarthrobacter, Pseudarthrobacter, Pseudomonas, and Rhodococcus. An important factor in the growth of the number of bacteria, in addition to the dose of biomass ash, was soil moisture, which in September was significantly higher than in April 2021 in both soils.
\end{abstract}

Keywords: biomass ashes; soil moisture; soil bacteria; microorganisms; fertilization; MALDI-TOF MS Biotyper

\section{Introduction}

Soil bacteria are microorganisms without which life on Earth could not exist. They are the key to the conversion of carbon and nitrogen in the soil, i.e., one of their most important components, which are often marginally addressed in research. The main functions of soil bacteria suggested by [1] are (1) providing nutrients to crops, (2) stimulating plant growth, e.g., via production of plant hormones, (3) controlling or inhibiting the activity of plant pathogens, (4) improving soil structure, and (5) bioaccumulation or leaching of inorganic substances [2,3]. Bacteria are also used in the bioremediation process for cleaning soils contaminated with toxic organic compounds, such as PAHs (polycyclic aromatic 
hydrocarbons) or pesticides [4-7]. Sustainable plant production should use the interactions between plants and microorganisms in the rhizosphere, which plays a key role in the transformation, mobilization, and solubilization of nutrients from forms that are difficult to access to those available for plants [8]. Soil bacteria are essential factors driving soil ecosystems and processes such as decomposition of organic matter, production of nutrients, and reduction of greenhouse gases. They play a key role as part of the lower trophic levels of the soil food web [9]. Thus, changes in the bacterial community may affect the functioning and quality of soil $[10,11]$. Literature data show that the highest concentration of microorganisms in soil occurs in the arable layer (surface) and around plant roots-the rhizosphere [12-15]. The life of microorganisms in the soil environment and the use of soils by humans are related to the alternating cycles of moistening and drying. Natural fluctuations in soil moisture and reoxidation are an important environmental variable directly influencing the metabolism of living microorganisms, which are strictly dependent on the physical condition of the soil [16-21]. Microorganisms react differently to a specific environmental factor, for example, soil water content or $\mathrm{pH}$, which may be lethal for some species and beneficial for the growth and development of other species [22-25]. It is estimated that a few grams of soil may contain tens of thousands of different species of bacteria [26].

Due to the necessity to care for the natural environment and sustainable circular economy, various types of wastes containing many valuable ingredients are used increasingly often for fertilization of soils and crops [27]. Ashes from biomass combustion, which have many nutrients beneficial to plants and can be used for cultivation, are this type of waste. In addition, due to the high content of alkaline compounds, they reduce the acidity of soil, which indirectly also increases its fertility. The use of ashes indirectly may also contribute to improvement of the chemical and biological properties of soils, mainly by increasing the $\mathrm{pH}$ value, especially in the case of acidic soils. Nevertheless, studies on the responses of soil bacterial communities to the application of wood ash are sparse, and the available results are inconclusive and remain at a general taxonomic level. Indirect measurements of the effect of wood ash on soil bacteria indicate an increase in overall mineralization [28-31] and decomposition [32-34]. The research conducted by Andreasen et al. [27] showed a significant increase in the $\mathrm{pH}$ of forest soil and significant changes in the composition of bacterial communities after applying high doses of ash. The present research aimed to assess the effect of the addition of various amounts of ash from biomass combustion in two types of soil on the number and species composition of soil bacteria in the conditions of a field experiment under the cultivation of oilseed rape.

\section{Materials and Methods}

A one-factor field experiment was established using the randomized block method (each block of approximately $162 \mathrm{~m}^{2}$ ) in triplicate. The tested variable factor was the applied fertilizer dose with ash from biomass combustion (Salix viminalis L. willow). The obtained results were compared with the control soil (without fertilization) and with soil where only NPK mineral fertilization was applied. The field experiment was established on podzolic and chernozem soils with the particle size distribution of silty loam (the division of the soils into the granulometric subgroups was based on the recommendations of the United States Department of Agriculture (USDA) [35] in autumn 2018 in Korzenica (Podkarpackie Voivodeship), Jarosław County, GPS coordinates: 500.02'16.3 N, 220.55'06.4 E). Winter oilseed rape (Brassica napus L. var. Napus) cv. Mandril (Syngenta) was grown on these soils. Biomass ash doses were balanced to the amount of potassium introduced into the soil. In all experiment variants, constant mineral fertilization with nitrogen $\left(81.3 \mathrm{~kg} \mathrm{~N} \mathrm{ha}^{-1}\right)$ and phosphorus (34 kg P ha ${ }^{-1}$ ) was applied.

The experiment included the following variants:

- Control-no $\mathrm{K}_{2} \mathrm{O}$ fertilization;

- $\quad \mathrm{NPK} \mathrm{K}_{2} \mathrm{O}$ in mineral fertilizers $\left(127 \mathrm{~kg} \mathrm{~K}_{2} \mathrm{O} \mathrm{ha}^{-1}\right)$;

- $100 \mathrm{~kg} \mathrm{~K}_{2} \mathrm{O} \mathrm{ha}^{-1}$ in ash (0.5 $\mathrm{t} \mathrm{ha}^{-1}$ of ash in bulk weight); 
- $\quad 200 \mathrm{~kg} \mathrm{~K}_{2} \mathrm{O} \mathrm{ha}{ }^{-1}$ in ash (1.0 $\mathrm{t} \mathrm{ha}^{-1}$ of ash in bulk weight);

- $\quad 300 \mathrm{~kg} \mathrm{~K}_{2} \mathrm{O} \mathrm{ha}^{-1}$ in ash (1.5 $\mathrm{t} \mathrm{ha}^{-1}$ of ash in bulk weight);

- $\quad 400 \mathrm{~kg} \mathrm{~K}_{2} \mathrm{O} \mathrm{ha}^{-1}$ in ash (2.0 $\mathrm{t} \mathrm{ha}^{-1}$ of ash in bulk weight);

- $\quad 500 \mathrm{~kg} \mathrm{~K}_{2} \mathrm{O} \mathrm{ha}^{-1}$ in ash ( $2.5 \mathrm{t} \mathrm{ha}^{-1}$ of ash in bulk weight).

The fertilization was applied before sowing. The doses and dates of application are presented in Table 1.

Table 1. Fertilizers used in the two-field experiment on podzolic and chernozem soils in 2018-2021.

\begin{tabular}{|c|c|c|c|c|}
\hline \multirow{2}{*}{ Fertilizer-Trade Name } & \multirow{2}{*}{$\begin{array}{c}\text { Amount of Pure } \\
\text { Component in } 100 \mathrm{~kg} \text { of } \\
\text { the Fertilizer }\end{array}$} & \multicolumn{2}{|c|}{ Dose (kg/L per 1 ha) } & \multirow{2}{*}{ Date of Application } \\
\hline & & Fertilizer & Pure Component & \\
\hline Biomass combustion ash & $\begin{array}{c}1.63 \% \mathrm{P}(3.73 \mathrm{~kg} \mathrm{P}) \\
19.4 \% \mathrm{~K}(23.37 \mathrm{~kg} \mathrm{~K}) \\
4.96 \% \mathrm{Mg}(8.222 \mathrm{~kg} \mathrm{Mg})\end{array}$ & \multicolumn{2}{|c|}{$\begin{array}{l}\text { Varied depending on the } \\
\text { experimental variant }\end{array}$} & $\begin{array}{l}30 \text { August } 2018 \\
29 \text { August } 2019 \\
25 \text { August } 2020\end{array}$ \\
\hline \multirow{2}{*}{$\begin{array}{c}\text { Monoammonium phosphate (MAP) } \\
\mathrm{NH}_{4} \mathrm{H}_{2} \mathrm{PO}_{4}\left(12 \% \mathrm{~N}-\mathrm{NH}_{4}, 52 \% \mathrm{P}_{2} \mathrm{O}_{5}, 22.7 \% \mathrm{P}\right)\end{array}$} & $22.7 \mathrm{~kg} \mathrm{P}$ & \multirow{2}{*}{150} & 34 & \multirow{2}{*}{$\begin{array}{l}30 \text { August } 2018 \text { (all variants) } \\
29 \text { August } 2019 \text { (all variants) } \\
25 \text { August } 2020 \text { (all variants) }\end{array}$} \\
\hline & $12 \mathrm{~kg} \mathrm{~N}$ & & 18 & \\
\hline Potassium salt (60\%) & $60 \mathrm{~kg} \mathrm{~K}$ & 175 & 105 & $\begin{array}{l}30 \text { August } 2018 \text { (NPK variant only) } \\
29 \text { August } 2019 \text { (NPK variant only) } \\
28 \text { August } 2020 \text { (NPK variant only) }\end{array}$ \\
\hline $\begin{array}{c}\mathrm{RSM}^{\circledR} 32 \% \mathrm{~N} \text { (aqueous solution of } \\
\text { urea-ammonium nitrate, density } 1.32 \mathrm{~kg} / \mathrm{dcm}^{3} \text { ) }\end{array}$ & $42.2 \mathrm{~kg} \mathrm{~N}(32 \times 1.32)$ & 150 & 63.3 & $\begin{array}{l}4 \text { March } 2019 \\
10 \text { March } 2020 \\
15 \text { March } 2021\end{array}$ \\
\hline
\end{tabular}

The composition of biomass ash used in the experiment for fertilization of winter oilseed rape on the podzolic and chernozem soils is presented in Table 2 [36].

Table 2. Composition of biomass ash used in the experiment for fertilization of winter oilseed rape on the podzolic and chernozem soils.

\begin{tabular}{|c|c|c|c|c|c|}
\hline $\mathrm{pH} \mathrm{H}_{2} \mathrm{O}$ & $\mathrm{EC} \mu \mathrm{S} \cdot \mathrm{cm}^{-1}$ & $\mathrm{Ca}\left(\mathrm{mg} \mathrm{kg}^{-1}\right)$ & $\mathrm{K}\left(\mathrm{mg} \mathrm{kg}{ }^{-1}\right)$ & $\mathrm{Na}\left(\mathrm{mg} \mathrm{kg}^{-1}\right)$ & $P\left(\mathrm{mg} \mathrm{kg}^{-1}\right)$ \\
\hline 12.82 & 8.81 & 145.081 & 129.617 & 1452 & 9244 \\
\hline
\end{tabular}

The soil was sampled at a $0-5 \mathrm{~cm}$ depth in triplicate from the arable layer in April and September 2021. The following physicochemical properties were determined in the soil samples after drying and sieving through a 2-mm mesh diameter. Soil reaction was measured with the potentiometric method using an HI-4221 pH meter (Hanna Instruments, Nusfalau, Romania) at a soil-to-solution ratio of 1:2.5. Soil electrolytic conductivity (EC), which is a measure of soil salinity, was determined with the conductometric method using an HI-2316 EC meter (Hanna Instruments, Nusfalau, Romania) at a soil-to-solution ratio of 1:2.5. Soil moisture was measured with the gravimetric method after drying to constant weight soil samples in Kopecki cylinders.

The impact of the biomass combustion ashes on the selected physicochemical properties of the podzolic and chernozem soils was analyzed using STATISTICA 13.3 software (StatSoft, Tulsa, OK, USA). One-way analysis of variance (ANOVA) was performed using the Tukey HSD multiple comparison test to identify homogeneous groups $(p<0.05)$.

\subsection{Microbiological Analysis}

\subsubsection{Soil Preparation for Microbiological Analysis}

The soil material (100 g each in triplicate) was collected into sterile bags at a depth of $0-5 \mathrm{~cm}$ of the experimental plots in April and September 2021. A collective 300-g sample was prepared from each plot. In order to determine the number of colony-forming units, PCA medium was prepared (BioMaxima SA, Lublin, Poland) according to the manufacturer's instructions. This medium is used to determine the total amount of microorganisms. One gram of soil was weighed from the pooled samples into sterile plastic test tubes, supplemented with $9 \mathrm{~mL}$ of distilled water, and vortexed for 5 min (Ohaus, Nänikon, Switzerland) at $1500 \mathrm{rpm}$. Serial dilutions of $10^{-2}$ and $10^{-3}$ were made and inoculated 
in a volume of $100 \mu \mathrm{L}$ in previously prepared Petri dishes. The dishes were incubated at $30{ }^{\circ} \mathrm{C}$ for $48 \mathrm{~h}$. The colonies were counted after the incubation period, and the number of microorganisms in $1 \mathrm{~g}$ of soil was calculated.

\subsubsection{Mass Spectrometry Identification of Isolates}

The sample for the MALDI-TOF MS Biotyper analysis was prepared according to the extraction procedure provided by the manufacturer (Bruker Daltonik, Bremen, Germany). The bacterial colony was suspended in $300 \mu \mathrm{L}$ of water (Sigma-Aldrich, St. Louis, MO, USA) and $900 \mu \mathrm{L}$ of absolute ethanol (Bruker Daltonik, Bremen, Germany), mixed ten times, and centrifuged at 13,000 rpm for $2 \mathrm{~min}$. The supernatant was rejected, and the pellets were centrifuged several times. After removal of the supernatant, the pellets were mixed with $10 \mu \mathrm{L}$ of $70 \%$ formic acid $(v / v)$ (Sigma-Aldrich, Saint Louis, MO, USA) and the same volume of acetonitrile (Sigma-Aldrich, Saint Louis, MO, USA). The mixture was centrifuged again and stained with $1 \mu \mathrm{L}$ of the supernatant on a polished steel target plate and airdried at room temperature. Then, $1 \mu \mathrm{L}$ of MALDI matrix (saturated solution of-cyano-4hydroxycinnamic acid, HCCA, Bruker Daltonik, Bremen, Germany) in 50\% acetonitrile and 2.5\% trifluoroacetic acid (Sigma-Aldrich, Saint Louis, MO, USA) was applied to each sample. The mass spectrometry results were generated automatically via the Microflex LT MALDI-TOF mass spectrometer (Bruker Daltonik, Bremen, Germany) working in a linearly positive mode in the mass range of 2000-20,000 Da. The device was calibrated using the Bruker bacterial standard. Spectrometric results were processed using MALDI Biotyper 3.0 software (Bruker Daltonik, Bremen, Germany). The following identification criteria were used: a score of 2300 to 3000 indicated highly probable identification at the species level; a score of 2000 to 2299 indicated safe genus identification with probable species identification; and a score of 1700 to 1999 indicated probable identification at the genus level.

\section{Results and Discussion}

Table 3 shows the meteorological conditions recorded in 2020 and 2021 when the samples were collected for the microbiological analysis during the experiment. The total annual precipitation in 2020 was $51.6 \mathrm{~mm}$, i.e., lower than in 2021. When the samples were taken, the monthly rainfall was $49.4 \mathrm{~mm}$ in April and $85.8 \mathrm{~mm}$ in September (a value higher by $36.4 \mathrm{~mm}$ ). Low precipitation reduces soil moisture, which affects all soil organisms, especially in its shallow layers.

Table 3. Data on weather conditions in 2020/2021 provided by the Meteorological Station of the University of Rzeszów.

\begin{tabular}{|c|c|c|c|c|c|c|c|c|}
\hline \multicolumn{5}{|c|}{ Temperature in ${ }^{\circ} \mathrm{C}$} & \multicolumn{4}{|c|}{ Precipitation in $\mathrm{mm}$} \\
\hline \multirow{3}{*}{ Month } & \multicolumn{7}{|c|}{2020} & \multirow{3}{*}{ Total } \\
\hline & \multicolumn{3}{|c|}{ Ten-Day Period } & \multirow{2}{*}{ Mean } & \multicolumn{3}{|c|}{ Ten-Day Period } & \\
\hline & I & II & III & & I & II & III & \\
\hline I & 0.5 & 2.3 & 1.4 & 1.4 & 3.9 & 0.1 & 7.9 & 11.8 \\
\hline II & 2.7 & 4.7 & 4.0 & 3.8 & 23.7 & 8.2 & 21.5 & 53.3 \\
\hline III & 5.3 & 7.2 & 2.9 & 5.1 & 15.0 & 2.9 & 2.0 & 19.8 \\
\hline IV & 7.9 & 8.5 & 11.2 & 9.2 & 0.0 & 4.7 & 5.3 & 10.0 \\
\hline $\mathrm{V}$ & 11.1 & 11.1 & 11.7 & 11.3 & 25.3 & 24.4 & 33.6 & 83.3 \\
\hline VI & 15.9 & 19.0 & 19.5 & 18.1 & 20.2 & 22.6 & 120.0 & 162.9 \\
\hline VII & 19.9 & 17.1 & 19.3 & 18.8 & 10.2 & 8.5 & 0.2 & 18.9 \\
\hline VIII & 20.2 & 19.5 & 20.1 & 19.9 & 0.2 & 0.1 & 7.0 & 7.3 \\
\hline IX & 15.7 & 14.7 & 14.5 & 15.0 & 4.2 & 0.0 & 39.3 & 43.5 \\
\hline$X$ & 13.8 & 8.3 & 11.1 & 11.1 & 16.8 & 30.4 & 7.1 & 54.3 \\
\hline XI & 12.9 & 8.5 & 10.6 & 10.6 & 17.5 & 29.8 & 8.1 & 55.4 \\
\hline XII & 7.5 & 6.4 & 1.0 & 5.0 & 7.4 & 2.3 & 5.6 & 15.3 \\
\hline \multicolumn{8}{|c|}{ Total } & 535.8 \\
\hline
\end{tabular}


Table 3. Cont.

\begin{tabular}{|c|c|c|c|c|c|c|c|c|}
\hline \multicolumn{5}{|c|}{ Temperature in ${ }^{\circ} \mathrm{C}$} & \multicolumn{4}{|c|}{ Precipitation in $\mathrm{mm}$} \\
\hline \multirow{3}{*}{ Month } & \multicolumn{4}{|r|}{2020} & & & & \multirow{3}{*}{ Total } \\
\hline & \multicolumn{3}{|c|}{ Ten-Day Period } & \multirow{2}{*}{ Mean } & \multicolumn{3}{|c|}{ Ten-Day Period } & \\
\hline & I & II & III & & I & II & III & \\
\hline & & & & 2021 & & & & \\
\hline I & 2.2 & -4.4 & 1.2 & -0.3 & 14.8 & 8.8 & 25.2 & 48.8 \\
\hline II & -2.3 & -5.7 & 4.4 & -1.2 & 31.3 & 14.9 & 1.9 & 48.1 \\
\hline III & 2.2 & 1.9 & 5.4 & 3.2 & 7.2 & 1.8 & 8.5 & 17.5 \\
\hline IV & 5.4 & 6.4 & 7.7 & 6.5 & 8.2 & 36.4 & 4.8 & 49.4 \\
\hline $\mathrm{V}$ & 11.4 & 14.1 & 13.0 & 12.8 & 21.2 & 15.6 & 27.1 & 63.9 \\
\hline VI & 15.7 & 18.6 & 22.2 & 18.8 & 9.0 & 6.8 & 31.5 & 47.3 \\
\hline VII & 21.1 & 22.8 & 21.0 & 21.6 & 29.3 & 16.5 & 9.2 & 55.0 \\
\hline VIII & 18.7 & 19.0 & 14.7 & 17.5 & 37.1 & 6.9 & 63.4 & 107.4 \\
\hline IX & 13.3 & 14.0 & 11.9 & 13.1 & 5.6 & 61.6 & 18.6 & 85.8 \\
\hline$x$ & 10.1 & 7.8 & 9.5 & 9.1 & 0.9 & 1.1 & 0.5 & 2.5 \\
\hline XI & 7.2 & 5.5 & 4.1 & 5.6 & 6.8 & 6.4 & 19.0 & 32.2 \\
\hline XII & 0.2 & 1.2 & -3.7 & -0.8 & 7.6 & 8.5 & 13.5 & 29.6 \\
\hline \multicolumn{8}{|c|}{ Total } & 587.4 \\
\hline
\end{tabular}

\subsection{Soil $p H$}

Soil $\mathrm{pH}$ is one of the most important parameters influencing soil fertility. All organisms living in the soil react relatively quickly to a change in reaction, especially microorganisms, including bacteria. Before the experiment was set up in September 2018, the $\mathrm{pH}$ of the podzolic soil was 5.83 , and the chernozem soil $\mathrm{pH}$ was 6.3 in the $0-5 \mathrm{~cm}$ layer. After three years of the experiment and application of the biomass ash with a $\mathrm{pH}$ value of 12.82, the $\mathrm{pH}$ of both soils increased by on average one unit (Figures 1 and 2). Changes in the value of the reaction in the last year are presented in Figure 1. The soil $\mathrm{pH}$ in April in all variants of the experiment was lower by one unit compared to September. Similar changes also occurred in the chernozem soil, and its average reaction in September was higher by one unit (Figure 2). The increase in the reaction caused by the application of the biomass combustion ash was not significant in any variant. Nevertheless, even a one-unit increase in $\mathrm{pH}$ can have an effect on soil microorganisms. Many authors $[9,27]$ indicate deacidifying properties of biomass ashes, and our experiment has shown that a high $\mathrm{pH}$ value of ashes does not always correspond to their deacidification capacity. It can be assumed that such a result is related to the high buffering capacity of the soil, weather conditions (rainfall), and ash properties, e.g., its ability to bind with soil particles, water solubility, etc. 


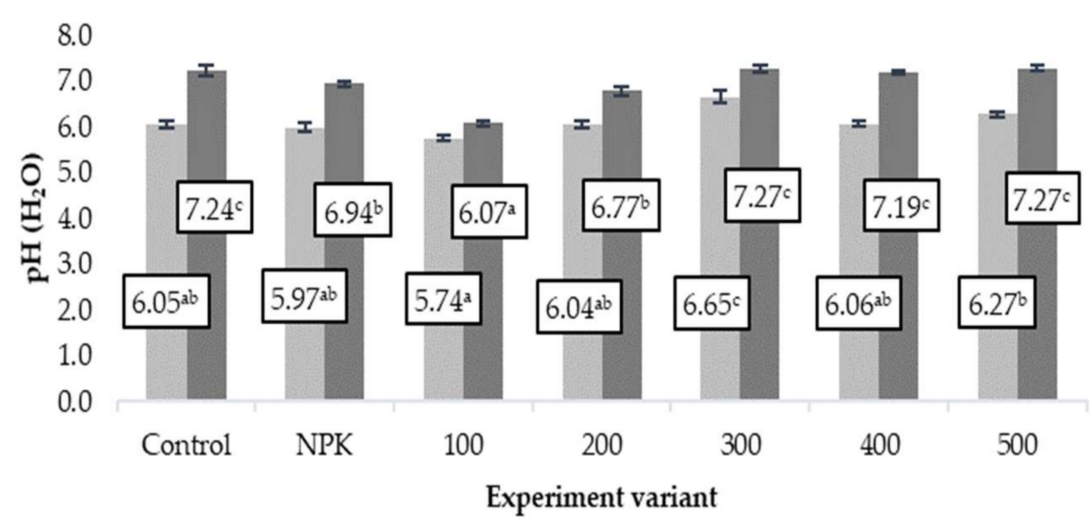

Figure 1. Changes in the $\mathrm{pH}$ of the podzolic soil in the $0-5 \mathrm{~cm}$ layer in IV (April) and IX (September) 2021 after the application of biomass combustion ashes (mean \pm SD). Treatments not sharing the same letter(s) are statistically significant at $p<0.05$ (Tukey's HSD).

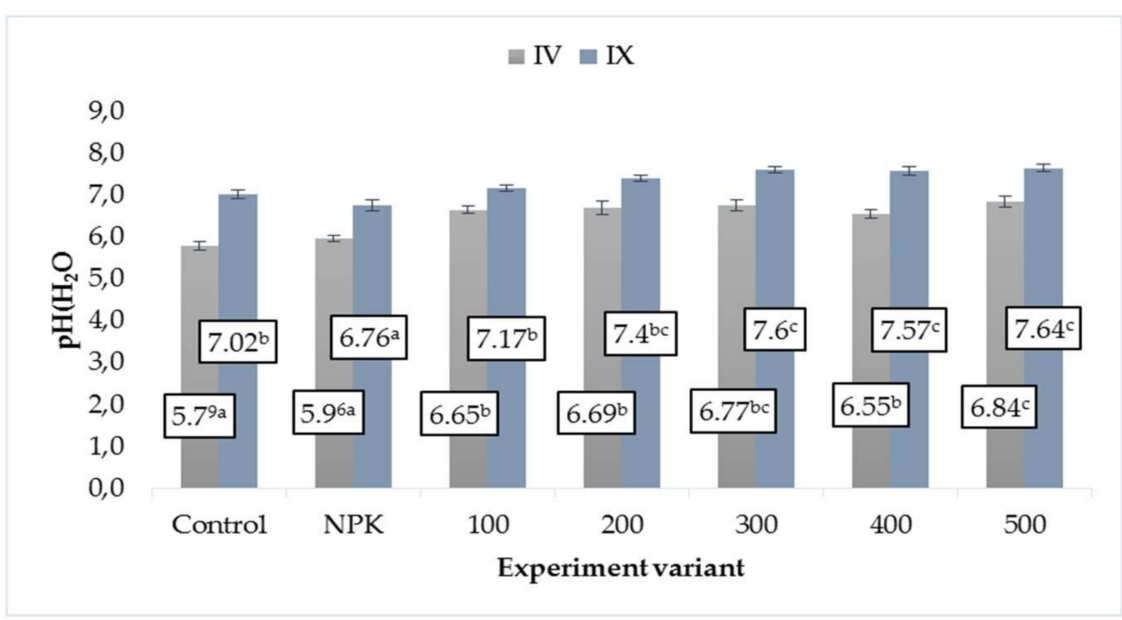

Figure 2. Changes in the $\mathrm{pH}$ of the chernozem soil in the $0-5 \mathrm{~cm}$ layer in IV (April) and IX (September) 2021 after the application of biomass combustion ashes (mean \pm SD). Treatments not sharing the same letter(s) are statistically significant at $p<0.05$ (Tukey's HSD).

\subsection{Salinity}

Mineral and organic fertilizers and ashes from biomass combustion applied into the soil may cause soil salinity. Figures 3 and 4 show the changes in electrolytic conductivity (EC) recorded from April to September, depending on the soil type. This is connected with the properties of different soil types and the mobility and reaction of substances that influence salinity. The EC value in the podzolic soil in April increased after the application of the doses from 200 to $500 \mathrm{~kg} \mathrm{~K}_{2} \mathrm{O} \mathrm{ha}^{-1}$ of biomass ash. In turn, the EC measured in September, in the upper soil level $(0-5 \mathrm{~cm})$ showed no significant differences between the variants. The analysis of the results obtained from the chernozem variants (Figure 4) showed the highest EC values in the NPK-fertilized variant and $200 \mathrm{~kg} \mathrm{~K}_{2} \mathrm{O} \mathrm{ha}^{-1}$ of biomass ash applied in April, and the other variants did not differ significantly. In September, the highest EC values were found in the variants fertilized with 100 and $200 \mathrm{~kg} \mathrm{~K}_{2} \mathrm{O}$ ha ${ }^{-1}$. The EC values in the two different soil types presented in this experiment did not have an adverse effect on the plants. 


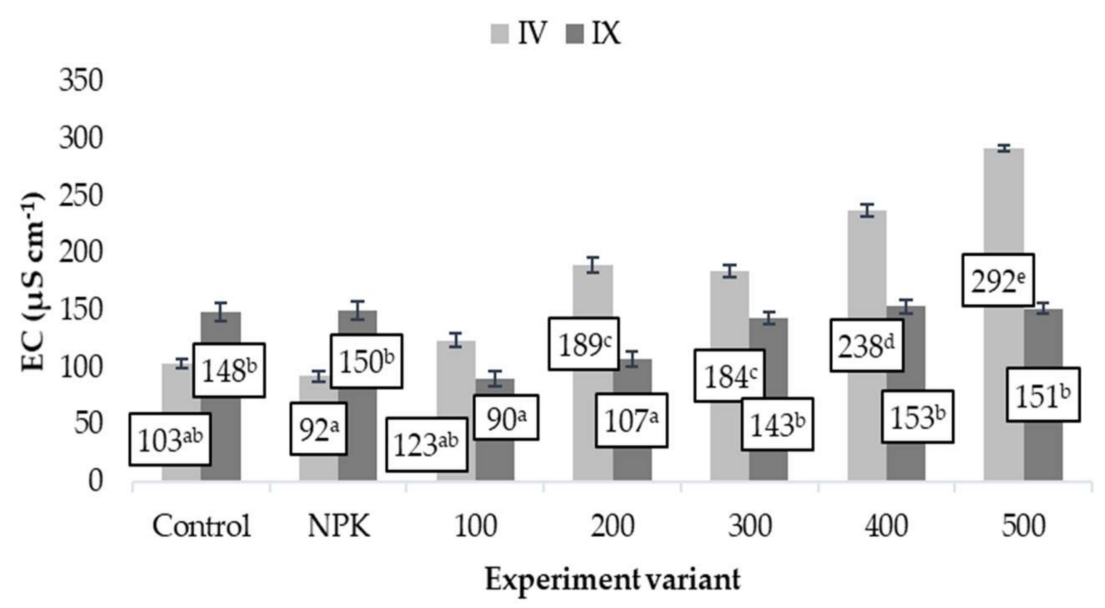

Figure 3. Changes in the salinity of the podzolic soil in the $0-5 \mathrm{~cm}$ layer in IV (April) and IX (September) 2021 after the application of biomass combustion ashes (mean \pm SD). Treatments not sharing the same letter(s) are statistically significant at $p<0.05$ (Tukey's HSD).

$\square \mathrm{IV} \backsim \mathrm{IX}$

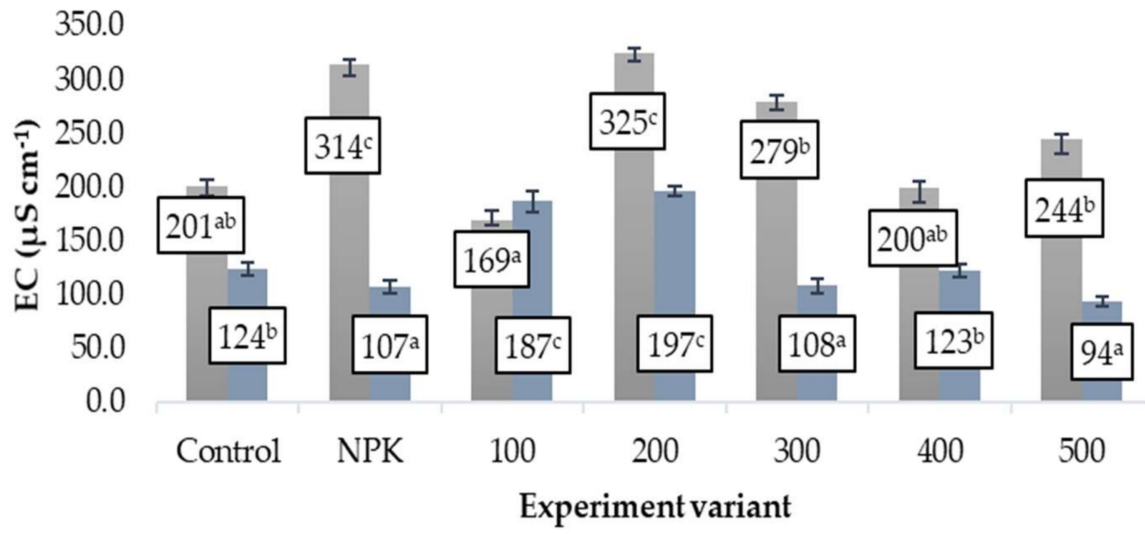

Figure 4. Changes in the salinity of the chernozem soil in the $0-5 \mathrm{~cm}$ layer in IV (April) and IX (September) 2021 after the application of biomass combustion ashes (mean \pm SD). Treatments not sharing the same letter(s) are statistically significant at $p<0.05$ (Tukey's HSD).

\subsection{Soil Moisture}

Soil moisture is closely related to the type of soil, i.e., its granulometric composition, water retention, material conditions (rainfall and temperature), and agrotechnical procedures. The analysis of the data on the weather conditions (Table 3) showed monthly rainfall of $49.4 \mathrm{~mm}$ in April and $85.8 \mathrm{~mm}$ in September, i.e., an almost two-fold higher value, which had a significant impact on the water content in the soil in the $0-5 \mathrm{~cm}$ layer. In September, moisture in the podzolic soil almost doubled in all variants (Figure 5). The use of biomass ash in the doses from 200 to $500 \mathrm{~kg} \mathrm{~K}_{2} \mathrm{O} \mathrm{ha}^{-1}$ resulted in a significant increase in moisture content in the case of the podzolic soil. In the case of the chernozem soil in April, increased water contents, which differed significantly, were recorded in variants fertilized with the biomass ash. In turn, in September (Figure 6), the water content in the soil was similar in all fertilization variants. 


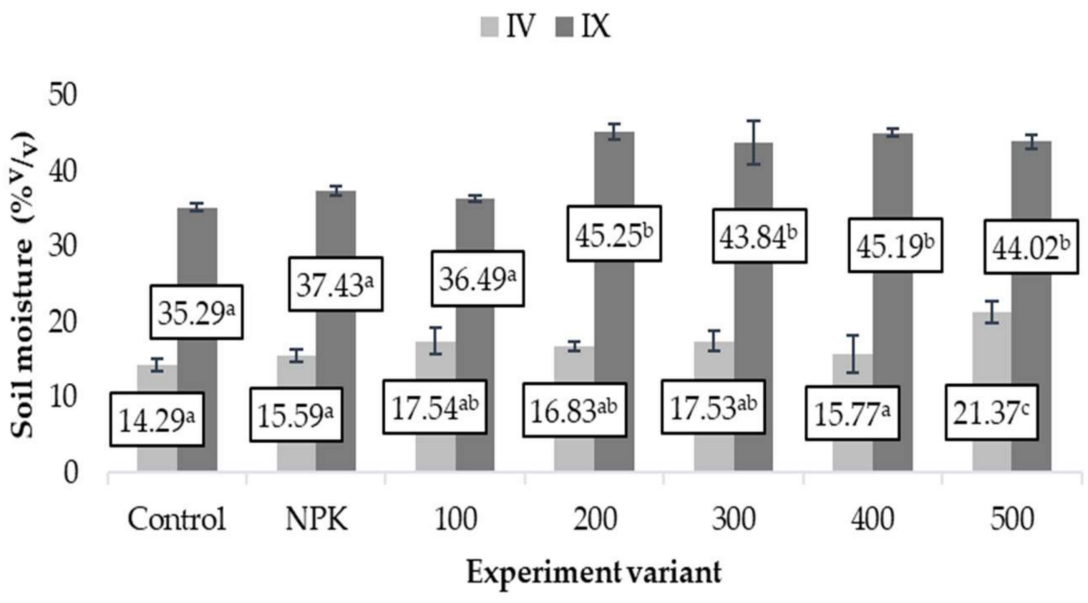

Figure 5. Changes in the moisture of the podzolic soil in IV (April) and IX (September) 2021 in the 0-5 cm layer after the application of biomass combustion ashes (mean $\pm \mathrm{SD}$ ). Treatments not sharing the same letter(s) are statistically significant at $p<0.05$ (Tukey's HSD).

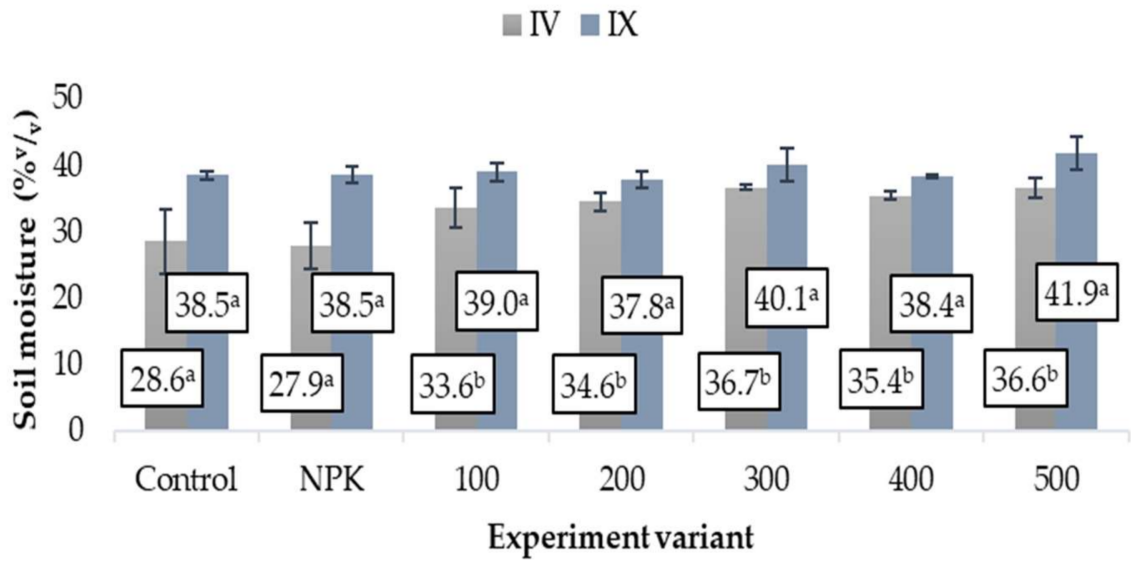

Figure 6. Changes in the moisture of the chernozem soil in IV (April) and IX (September) 2021 in the 0-5 cm layer after the application of biomass combustion ashes (mean $\pm \mathrm{SD}$ ). Treatments not sharing the same letter(s) are statistically significant at $p<0.05$ (Tukey's HSD).

\subsection{Microorganisms}

The activity and abundance of soil microorganisms is closely related to many factors such as soil type, type of crops, temperature, $\mathrm{pH}$, and soil moisture [37]. The field research was carried out on two types of soil: podzolic and chernozem soil, where biomass ash was used for fertilization in various doses. Based on the conducted microbiological analyses, it was found that, in both examined soils (Figures 7 and 8), there was a visible growth of microorganisms depending on the method and dose of fertilization. The control podzolic and chernozem soil contained from 6.0 to $6.6 \times 10^{4}$ colony forming units/gram dry mass (CFU/g d.m.) and from 6.2 to $7.2 \times 10^{4} \mathrm{CFU} / \mathrm{g}$ d.m., respectively. In turn, in the NPKfertilized variants, from 6.4 to $6.9 \times 10^{4} \mathrm{CFU} / \mathrm{g}$ d.m. and from 7.5 to $9.0 \times 10^{4} \mathrm{CFU} / \mathrm{g} \mathrm{d} . \mathrm{m}$. were detected in the podzolic and chernozem soils, respectively. After the use of biomass ash, the number of bacteria increased with the increasing doses, i.e., the bacterial counts after the application of the dose of $500 \mathrm{~kg} \mathrm{~K}_{2} \mathrm{O} \mathrm{ha}^{-1}$ were $22.2 \times 10^{4} \mathrm{CFU} / \mathrm{g} \mathrm{d}$.m. of soil in April and $31.0 \times 10^{4} \mathrm{CFU} / \mathrm{g}$ d.m. of soil in September. The tendency of the increase in the bacterial number depending on the ash dose in the chernozem soil was similar to that in the podzolic soil. In the chernozem soil fertilized at the dose of $500 \mathrm{kgK}_{2} \mathrm{O} \mathrm{ha}^{-1}$, there were $19.0 \times 10^{4} \mathrm{CFU} / \mathrm{g}$ d.m. in April and $25.5 \times 10^{4} \mathrm{CFU} / \mathrm{g}$ d.m. of soil in September (Figure 8). It can be concluded that the increasing doses of biomass ash had a positive effect on the number of bacteria in both analyzed soils. Both soils exhibited differences in the number of 
bacteria related to the sampling time, i.e., April and September. This is probably related to soil moisture. In September, the rainfall rate was higher by $36.4 \mathrm{~mm}$ than in April, which resulted in higher soil moisture by an average of $10 \%$ in the podzolic soil and $20 \%$ in the chernozem soil.

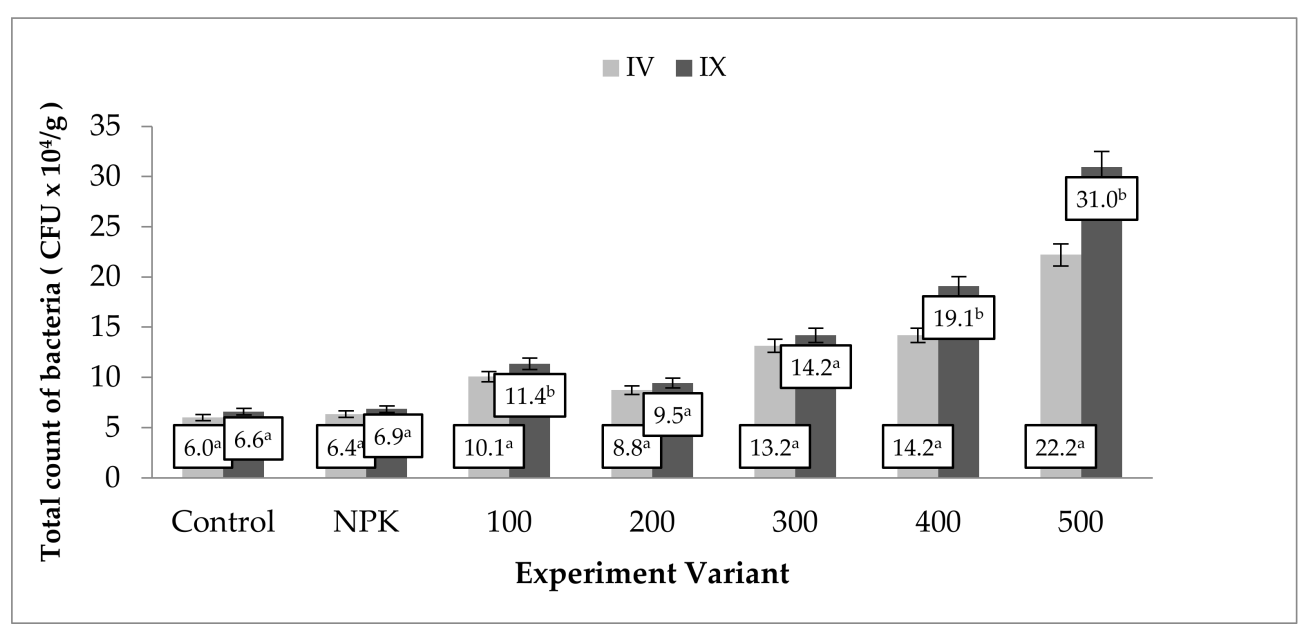

Figure 7. Differences in the number of bacteria (expressed in CFU $\times 10^{4} / \mathrm{g}$ of dry soil) in the podzolic soil in the layer of $0-5 \mathrm{~cm}$ after the application of different doses of the ash fertilizer. Treatments not sharing the same letter(s) are statistically significant at $p<0.05$ (Tukey's HSD).

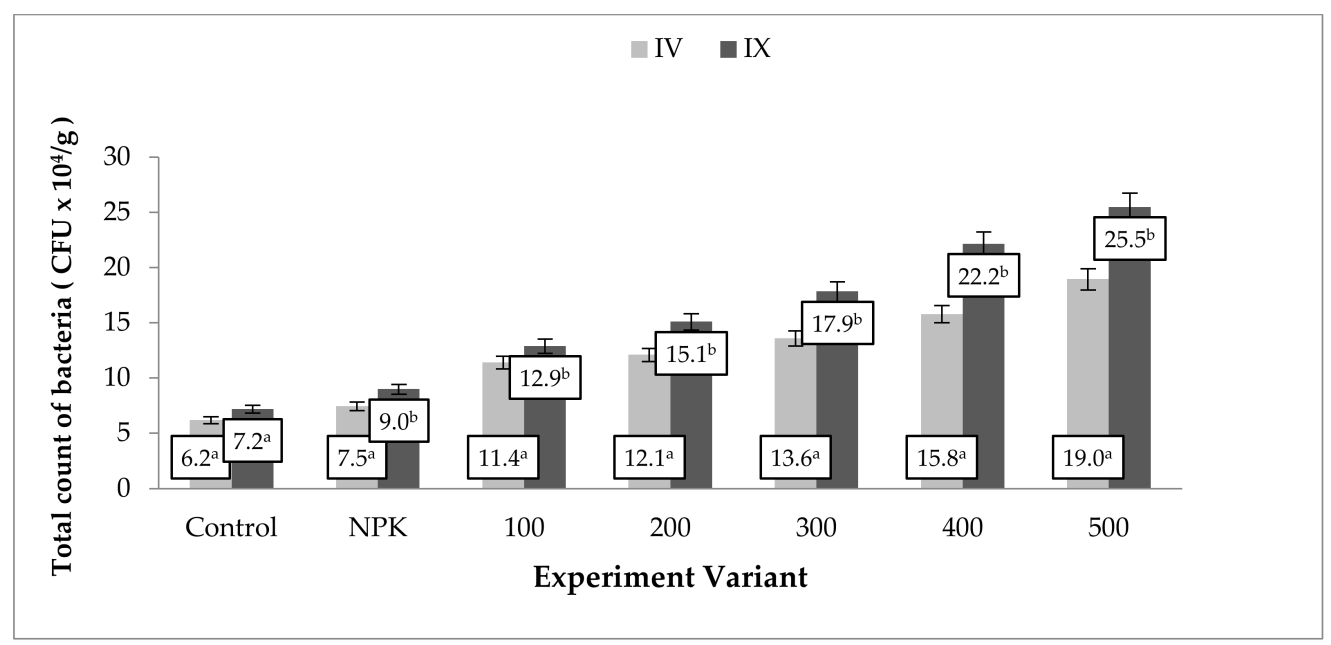

Figure 8. Differences in the number of bacteria (expressed in CFU $\times 10^{4} / \mathrm{g}$ of dry soil) in the chernozem soil in the layer of $0-5 \mathrm{~cm}$ after the application of different doses of the ash fertilizer. Treatments not sharing the same letter(s) are statistically significant at $p<0.05$ (Tukey's HSD).

Due to its properties, ash can be an alternative fertilizer in agriculture, and its use as a fertilizer leads to safe utilization and management of soil nutrients [38]. However, there are no studies on its impact on microorganisms and their activity [39]. Bacteria in the soil play a significant role in its fertilization through the degradation of organic matter and the transformation of soil components. However, their quantity and effect are also influenced by soil properties. The literature describes interactions between plant species, soil, and microbial communities [40]. The type of soil was considered to be the determinant of the composition of the microbial population in arable soils [41]. However, other authors [42] have shown that, in the same soil type, different plant species influence the distribution of the microbial population. In our experiment, the same plant, i.e., winter rape, was grown on both soils to eliminate the influence of the factor of different plants. 
MALDI-TOF MS Biotyper is suitable for clinical isolates identification. In recent years, MALDI-TOF MS Biotyper has been shown to be suitable for soil bacteria. In our work we use the identification of bacteria isolated from the soil via mass spectrometry. To evaluate bacterial species, we use our own database created on the basis of individual species of bacteria isolated from the soil and subsequently identified using molecular methods [43].

A total of 44 species of bacteria were identified in the podzolic and chernozem soils. They belonged to the genera Bacillus, Paenarthrobacter, Pseudarthrobacter, Pseudomonas, and Rhodococcus (Table 4). The most frequently identified microorganism was Bacillus megaterium, while Pseudomonas grimontii was the least common species. The podzolic soil was characterized by a greater diversity of bacteria -5 genera were identified, compared to the chernozem soil, where 3 genera were identified, i.e., Bacillus, Paenarthrobacter, and Pseudomonas. However, the podzolic soil was characterized by a lower number of identified microorganisms (27 strains) compared to the chernozem soil (37 strains). In both types of soil, an increase in the number of identified microorganisms was noticed in the samples collected in September compared to April. This may be associated with the higher soil moisture, and such a relationship was highlighted by [44]. The control and NPK-fertilized samples showed a low level of identification of microorganisms in relation to the plots where the differentiated fertilization with biomass ash was applied. Most of the bacteria were identified in the samples from the plots with the addition of ash and were not observed for the control sample and standard NPK fertilization. The results presented by us prove the positive effect of ash on the composition of the bacterial community. A similar effect was found by Andreasen et al., in their research [27]. The highest number of identified bacteria (25) was found in the podzolic soil samples in September fertilized with a dose of $500 \mathrm{~kg} \mathrm{~K}_{2} \mathrm{O} \mathrm{ha}^{-1}$ in ash. Compared to April, this was a two-fold increase (Table 4). Similar results were obtained in the chernozem soil, i.e., a significant increase in the determined bacterial strains in September (22) compared with April (16), at the dose of $500 \mathrm{~kg} \mathrm{~K}_{2} \mathrm{O}^{-1}$ in ash. The total number of microorganisms measured in soils stimulated with the biomass combustion ash in all tested samples was higher compared to the control sample and the NPK-fertilized soil. The autumn test with the ash dose of $500 \mathrm{~kg} \mathrm{~K}_{2} \mathrm{O} \mathrm{ha}^{-1}$ applied in the podzolic soil showed the most significant increase in the number of microorganisms. The increase in the number of bacteria after the application of ash was also reported in the literature $[33,45,46]$. The higher count of bacteria in the samples collected in September is related to the higher soil moisture [44,47]. The number of soil microorganisms is most likely caused by the presence of rapidly growing copiotrophs in favorable conditions, such as soil fed with ash [27]. The better growth of this group of bacteria after the use of biomass combustion ash is probably associated with the increased availability of nutrients. Ash contains many ingredients, and some of them have a nourishing effect on soil bacteria. However, it can cause changes in the soil system, which in turn leads to the lysis of microorganisms, thanks to which easily digestible nutrients are released. The $\mathrm{pH}$ of the soil also influences the bioavailability of nutrients in the soil and improves the conditions favorable for bacteria [48].

Soil bacteria play an important role in biogeochemical cycles and plant production. The interactions of bacteria with plants in the rhizosphere are reflected in plant health and soil fertility. The relationship of plant growth-promoting rhizobacteria (PGPR) with plants is complex and interdependent and includes not only two partners but also other biotic and abiotic factors in the rhizosphere [49].

Plant growth-promoting bacteria are free-living soil bacteria that can directly or indirectly facilitate rooting [50] and plant growth [51]. Over the past years, the number of identified PGPR has increased due to the increased importance of the role of the rhizosphere as an ecological unit in the functioning of the biosphere and the deeper understanding of the mechanisms of action of PGPRs. 
Table 4. List of bacterial species identified using MALDI-TOF MS in the podzolic and chernozem soils under winter rape cultivation in April and September 2021. Control (without fertilization), NPK $\mathrm{K}_{2} \mathrm{O}$ in mineral fertilizers, $100-100 \mathrm{~kg} \mathrm{~K}_{2} \mathrm{O}^{-1}$ in ash, 200-200 kg K ${ }_{2} \mathrm{O} \mathrm{ha}^{-1}$ in ash, 300-300 kg K $\mathrm{O}^{-}$ha ${ }^{-1}$ in ash, $400-400 \mathrm{~kg} \mathrm{~K}_{2} \mathrm{O} \mathrm{ha}^{-1}$ in ash, $500-500 \mathrm{~kg} \mathrm{~K}_{2} \mathrm{O} \mathrm{ha}^{-1}$ in ash.

\begin{tabular}{|c|c|c|c|c|c|c|c|c|c|c|c|c|c|c|c|c|c|c|c|c|c|c|c|c|c|c|c|c|}
\hline \multirow{3}{*}{ Taxa } & \multicolumn{14}{|c|}{ Podzolic Soil } & \multicolumn{14}{|c|}{ Chernozem Soil } \\
\hline & \multicolumn{7}{|c|}{ IV } & \multicolumn{7}{|c|}{$\mathrm{IX}$} & \multicolumn{7}{|c|}{ IV } & \multicolumn{7}{|c|}{ IX } \\
\hline & Control & NPK & 100 & 200 & 300 & 400 & 500 & Control & NPK & 100 & 200 & 300 & 400 & 500 & Control & NPK & 100 & 200 & 300 & 400 & 500 & Control & NPK & 100 & 200 & 300 & 400 & 500 \\
\hline Bacillus cereus & + & & + & & + & & + & & + & + & + & + & + & + & + & & + & & + & & + & + & & + & & + & + & + \\
\hline Bacillus cytotoxicus & & & & & & & & & & & & & + & + & & & & & & & & & & & & & & \\
\hline Bacillus megaterium & & + & & + & + & + & + & & + & + & + & + & + & + & & & + & + & + & + & & & & + & + & + & + & + \\
\hline Bacillus mycoides & & & + & + & & + & & & & + & + & + & + & + & & & + & & + & & & & & + & & + & + & + \\
\hline $\begin{array}{c}\text { Bacillus } \\
\text { pseudomycoides }\end{array}$ & & & + & & & & + & & & + & & + & + & + & & & & & & & & & & & & & & \\
\hline Bacillus simplex & & & & . & & & & & & & & & + & + & & & & + & & & & & & & + & & & \\
\hline $\begin{array}{c}\text { Bacillus } \\
\text { weihenstephanensis }\end{array}$ & & & + & + & + & + & & & & + & + & + & + & + & & & + & & & & & & & + & & + & & \\
\hline $\begin{array}{c}\text { Paenarthrobacter } \\
\text { aurescens }\end{array}$ & & & & & & & & & & & & & + & + & & & & & & & + & & & & & & + & + \\
\hline $\begin{array}{l}\text { Paenarthrobacter } \\
\text { histidinolovorans }\end{array}$ & & & & & & & + & & & & & & & + & & & & & & & + & & & & & + & & + \\
\hline $\begin{array}{c}\text { Paenarthrobacter } \\
\text { ilicis }\end{array}$ & & & & . & & & & & & & & & & & & & + & & & & + & & & + & & & & + \\
\hline $\begin{array}{c}\begin{array}{c}\text { Paenarthrobacter } \\
\text { nicotinovorans }\end{array} \\
\end{array}$ & & & & & & & & & & & & & & & & & + & & & & & & & + & & & + & \\
\hline $\begin{array}{l}\text { Pseudarthrobacter } \\
\text { chlorophenolicus }\end{array}$ & & & & & & + & & & & & & & + & + & & & & & & & & & & & & & & \\
\hline $\begin{array}{l}\text { Pseudarthrobacter } \\
\text { polychromogenes }\end{array}$ & & & & + & & & & & & & + & & & + & & & & & & & & & & & & & & \\
\hline Pseudomonas agarici & & & & . & & & . & & & & & & & 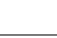 & & & & & + & & & & & & & + & + & \\
\hline $\begin{array}{c}\begin{array}{c}P \text { seudomonas } \\
\text { antarctica }\end{array} \\
\text { a }\end{array}$ & & & & & & & & & & & & & & & & & & & & & + & & & & + & & + & + \\
\hline $\begin{array}{l}\begin{array}{l}\text { Pseudomonas } \\
\text { azotoformans }\end{array} \\
\text { and }\end{array}$ & & & & & & & + & & & & & & & + & & & & & & & & & & & & & & \\
\hline $\begin{array}{l}\text { Pseudomonas } \\
\text { brassicacerrum }\end{array}$ & & & + & & & & & & & + & & + & & + & & & + & & + & + & & & & + & & + & + & + \\
\hline $\begin{array}{c}\text { Pseudomonas } \\
\text { brenneri }\end{array}$ & & & & & & & + & & & & & & & + & & & & & & & & & & & & & & \\
\hline $\begin{array}{l}\text { Pseudomonas cedrina } \\
\text { ssp. cedrina }\end{array}$ & & & & & & & & & & & & & & & & & & & & & + & & & & & & & + \\
\hline $\begin{array}{c}\begin{array}{c}\text { Pseudomonas } \\
\text { chlororaphis }\end{array} \\
\text { chats }\end{array}$ & & & & & & & & & & & & & & & & & & & + & & & & & & & + & + & + \\
\hline $\begin{array}{l}\text { Pseudomonas } \\
\text { chlororaphis sp. } \\
\text { aurantiacs }\end{array}$ & & & & & & & + & & & & & & & + & & & + & + & + & + & + & & & + & + & + & + & + \\
\hline
\end{tabular}


Table 4. Cont.

\begin{tabular}{|c|c|c|c|c|c|c|c|c|c|c|c|c|c|c|c|c|c|c|c|c|c|c|c|c|c|c|c|c|}
\hline \multirow{3}{*}{ Taxa } & \multicolumn{14}{|c|}{ Podzolic Soil } & \multicolumn{14}{|c|}{ Chernozem Soil } \\
\hline & \multicolumn{7}{|c|}{ IV } & \multicolumn{7}{|c|}{ Ix } & \multicolumn{7}{|c|}{ IV } & \multicolumn{7}{|c|}{ Ix } \\
\hline & Control & NPK & 100 & 200 & 300 & 400 & 500 & Control & NPK & 100 & 200 & 300 & 400 & 500 & Control & NPK & 100 & 200 & 300 & 400 & 500 & Control & NPK & 100 & 200 & 300 & 400 & 500 \\
\hline $\begin{array}{c}\text { Pseuddomonos } \\
\text { chlororaphis ssp. } \\
\text { chlororaphis }\end{array}$ & & & & & & & & & & & & & & & & & & + & & + & + & & & & + & & + & + \\
\hline $\begin{array}{c}\begin{array}{c}\text { Pseudomonas } \\
\text { corrugata }\end{array} \\
\text { a }\end{array}$ & & & & & & & & & & & & & & & & & + & & + & + & + & & & + & + & + & + & + \\
\hline $\begin{array}{c}\text { Pseudomonas } \\
\text { extremorientalis }\end{array}$ & & & & & & & + & & & & & & & + & & & & & & & + & & & & & + & & + \\
\hline 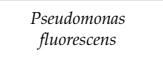 & & & & & & & & & & & & & & & & & & & & & + & & & & & + & + & \\
\hline $\begin{array}{c}\text { Pseudomonas } \\
\text { grimontii }\end{array}$ & & & & & & & + & & & & & & & & & & & & & & & & & & & & & \\
\hline $\begin{array}{c}\begin{array}{c}\text { Pseudomonas } \\
\text { graminis }\end{array} \\
\end{array}$ & & & & & & & + & & & & & & & & & & + & & & & & & & + & & & & \\
\hline $\begin{array}{c}\text { Pseudomonas } \\
\text { gessartii }\end{array}$ & & & + & & + & & & & & + & + & + & + & + & & & & & & & & & & & & & & \\
\hline Pseudomonas jessenii & & & & & & & & & & & & & & & & & & + & + & + & + & & & . & + & + & + & + \\
\hline $\begin{array}{c}\text { Pseuddomonas } \\
\text { kilonensis }\end{array}$ & & & & & & & & & & & & & & & & & + & & + & + & & & & + & & + & + & \\
\hline $\begin{array}{c}\begin{array}{c}\text { Pseudomonas } \\
\text { libanensis }\end{array} \\
\end{array}$ & & & . & & & & & & & & & & & & & & & & & & + & & & & & & & + \\
\hline $\begin{array}{c}\text { Pseudomonas } \\
\text { oleocorans }\end{array}$ & & & & & & & & & & & & & & & & & + & & & & & & & + & + & & & \\
\hline Pseudomonas poae & & & . & & & & . & & & & & & & & & & & & & & + & & & & & + & . & + \\
\hline $\begin{array}{c}\text { Pseudomonas } \\
\text { protegens }\end{array}$ & & & & & & & & & & & & & & & & & & & & + & & & & & & + & + & \\
\hline Pseudomonas putida & & & & & & & + & & & & & & & + & + & & & + & & & . & + & & & + & + & 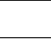 & 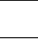 \\
\hline 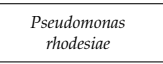 & & & & & & & + & & & & & & & + & & & & & & & + & & & & & & & + \\
\hline $\begin{array}{l}\text { Pseudomonas } \\
\text { thivervalensis }\end{array}$ & & & + & & & & & & & + & & & & + & & & + & & + & + & & & & + & & + & + & + \\
\hline $\begin{array}{c}\text { Pseudomonas } \\
\text { trivialis }\end{array}$ & & & & & & & & & & & & & & & & & & & & & + & & & & & & & + \\
\hline $\begin{array}{l}\text { Pseuddomonas } \\
\text { vancouverensis }\end{array}$ & & & + & & & & & & & + & & & & + & & & & & + & & & & & & & + & + & \\
\hline Pseudomonas veronii & & & & & & & & & & & & & & & & & & & & & + & & & & & & + & + \\
\hline $\begin{array}{c}\text { Rhodococcus } \\
\text { globerulus }\end{array}$ & & & & & + & & & & & & & + & & + & & & & & & & & & & & & & & \\
\hline Total & 1 & 1 & 10 & 5 & 6 & 5 & 13 & 0 & 2 & 11 & 8 & 11 & 12 & 25 & 2 & 1 & 14 & 5 & 14 & 9 & 16 & 2 & 1 & 15 & 8 & 20 & 20 & 22 \\
\hline
\end{tabular}


PGPR are classified as bacteria that have a positive effect on the plant. Through competition with existing bacterial communities in the rhizosphere, PGPR are a tool of sustainable agriculture and a trend for the future. These bacteria belong to the genera Acetobacter, Acinetobacter, Alcaligenes, Arthrobacter, Azoarcus, Azospirillum, Azotobacter, Bacillus, Beijerinckia, Burkholderia, Derxia, Enterobacter, Gluconacetobacter, Herbaspirillum, Klebsiella, Ochrobactrum, Pantoae, Paenarthrobacter, Pseudarthrobacter, Pseudomonas, Rhodococcus, Serratia, Stenotrophomonas, and Zoogloea and have been the subject of extensive research over the years [52,53].

One of the mechanisms by which bacteria are adsorbed on soil particles is simple ion exchange, and soil is said to be naturally fertile when soil organisms release inorganic nutrients from organic reserves at a rate sufficient to sustain rapid plant growth.

The most frequently identified group of bacteria was Pseudomonas, which arouses great interest among scientists studying sustainable agriculture, as these bacteria are shown to contribute to plant growth and induced systemic resistance (ISR) as a result of various activities, such as inhibition of plant diseases, better absorption of nutrients, or production of phytohormones. Pseudomonas is an aerobic, Gram-negative representative of Gammaproteobacteria from the family Pseudomonadaceae containing about 191 diverse species. Through its metabolic versatility and plasticity to genetic changes, this group is ubiquitous in the soil ecosystem. It is used as a bio-identifier, i.e., plant growth control, and as a means of biological control (protection against diseases) [54-57]. Pseudomonas bacteria are involved in solubilization of inorganic phosphorus [58], production of iron-chelating siderophores [59], and modulation of phytohormone levels [60]. They also have antifungal properties [61] and can produce antibiotics [62].

Another equally large group identified in our study was Bacillus. It produces resistant spores and can secrete metabolites that stimulate plant growth and prevent pathogenic infections [63]. Microbes of this genus inhabit the rhizosphere and lead to improved tolerance to abiotic and biotic stress through the production of specific hormones [64]. Bacillus spp. are also capable of producing exopolysaccharides and siderophores, which inhibit the flow of toxic ions and help maintain ionic balance, promote water movement in plant tissues, and inhibit the growth of pathogenic microorganisms [63].

Equally interesting are the bacteria of the genera Paenarthrobacter and Pseudarthrobacter found in our soils, which until 2016 were classified as Arthrobacter species [65]. These bacteria can use inorganic and organic compounds as a substrate for metabolism, thus leading to bioremediation activity, i.e., removal of impurities from the soil and groundwater through living microorganisms inhabiting mainly the rhizosphere zone [66]. Many strains from this group have a beneficial effect on the growth and yield of plants. They protect plants against abiotic stress, such as high salinity and drought [67]. An important feature of this group of bacteria is the possibility of biodegradation of atrazine, which is indicated by numerous studies [68-71], simazine [72], chromium [73], and polychlorinated biphenyls [74,75]. Joshi et al. [76] found that they are capable of degrading hydrocarbons, herbicides, and pesticides, reducing iron uptake, and phenylacetic acid degradation.

Only one strain from this group of bacteria was identified, namely Rhodococcus globerulus, which can prevent pathogenic infection in plants and has probiotic properties [77]. It has the ability to remove oil associated with contaminated soils [78].

\section{Conclusions}

Soil bacteria play important functions in soil ecosystems. However, the effects of ash on soil microbiota have been poorly explored. The field tests carried out in 2021 on two different types of soils with the use of different doses of biomass ash showed a significant effect of the ash on the presence of bacteria. Forty-four taxa were identified. However, in addition to fertilization, the soil moisture $\mathrm{pH}$ is a determining factor. Many environmental factors can also influence the diversity of soil microorganisms. The application of fertilization with ash with a $\mathrm{pH}$ of $12.83 \pm 0.68$ did not cause a significant increase in the $\mathrm{pH}$ of the tested soils. In addition, despite the increase in the mean EC values caused 
by the NPK fertilization and ash, compared to the control, the salt concentration in the soil solution was within the range tolerated by all plant species. The application of the increasing doses of biomass ash did not increase the salinity of the soil. Soil bacteria are one of the most important elements improving soil fertility. However, not much is known about the ecological preferences of bacteria, especially those beneficial for plant development and related to the degradation of various substances in the soil. There are also few studies on the impact of using ash from biomass combustion or other ash on microorganisms, i.e., soil bacteria. More research on the effect of fertilization, the physical and chemical properties of the soil, and the plants themselves on soil bacteria is needed.

Author Contributions: Conceptualization. J.S.-T. and E.S.-K.; methodology J.S.-T., M.K., K.S. and M.P.; investigation M.K., M.I.K. and R.P.; writing-original draft preparation. J.S.-T., M.P., E.A.C. and K.P.; formal analysis. J.S.-T. All authors have read and agreed to the published version of the manuscript.

Funding: The research (J.S.-T., M.P., R.P. and K.S.) on soil material was funded within a subsidy to maintain the research potential of the Department of Soil Science, Environmental Chemistry and Hydrology of the University of Rzeszów for 2018/2019/2020/2021.

Institutional Review Board Statement: Not applicable.

Informed Consent Statement: Not applicable.

Data Availability Statement: The entire set of raw data presented in this study is available on request from the corresponding author.

Conflicts of Interest: The authors declare no conflict of interest.

\section{References}

1. Davison, J. Plant Beneficial Bacteria. Nat. Biotechnol. 1988, 6, 282-286. [CrossRef]

2. Brierley, J.A. Use of microorganisms for mining metals. In Engineered Organisims in the Environment: Scientifc Issues; Halvorson, H.O., Pramer, D., Rogul, M., Eds.; ASM Press: Washington, DC, USA, 1985; pp. 141-146.

3. Ehrlich, H.L. Geomicrobiology. Geomicrobiol. J. 1990, 2, 646.

4. Middledrop, P.; Briglia, M.; Salkinoja-Salonen, M. Biodegradation of Pentachlorophenol in Natural Polluted Soil by Inoculated Rhodococcus chlorophenolicus. Microb. Ecol. 1990, 20, 123-139. [CrossRef] [PubMed]

5. Burd, G.I.; Dixon, D.G.; Glick, B.R. Plant Growth-Promoting Bacteria That Decrease Heavymetal Toxicity in Plants. Can. J. Microbiol. 2000, 46, 237-245. [CrossRef] [PubMed]

6. Zhuang, X.; Chen, J.; Shim, H.; Bai, Z. New Advances in Plant Growth-Promoting Rhizobacteria for Bioremediation. Environ. Int 2007, 33, 406-413. [CrossRef] [PubMed]

7. Zaidi, S.; Usmani, S.; Singh, B.R.; Musarrat, J. Significance of Bacillus subtilis Strains SJ-101 as a Bioinoculant for Concurrent Plant Growth Promotion and Nickel Accumulation in Brassica juncea. Chemosphere 2008, 64, 991-997. [CrossRef] [PubMed]

8. Hayat, R.; Ali, S.; Amara, U.; Khalid, R.; Ahmed, I. Soil Beneficial Bacteria and Their Role in Plant Growth Promotion: A Review. Ann. Microbiol. 2010, 60, 579-598. [CrossRef]

9. Paul, E.A. Soil Microbiology, Ecology, and Biochemistry; Academic Press: Cambridge, MA, USA, $2014 ;$ p. 576.

10. Philippot, L.; Raaijmakers, J.M.; Lemanceau, P.; van der Putten, W.H. Going Back to the Roots: The Microbial Ecology of the Rhizosphere. Nat. Rev. Microbiol. 2013, 11, 789-799. [CrossRef]

11. Wittebolle, L.; Marzorati, M.; Clement, L.; Balloi, A.; Daffonchio, D.; Heylen, K.; De Vos, P.; Verstraete, W.; Boon, N. Initial community evenness favours functionality under selective stress. Nature 2009, 458, 623-626. [CrossRef]

12. Nannipieri, P.; Ascher, J.; Ceccherini, M.T.; Landi, L.; Pietramellara, G.; Renella, G. Microbial Diversity and Soil Functions. Eur. J. Soil Sci. 2003, 54, 655-670. [CrossRef]

13. Kunicki-Goldfinger, W.J.H. Życie Bakterii; Wydawnictwo Naukowe PWN: Warszawa, Poland, 2008.

14. Lee, S.-H.; Oh, B.-I.; Kim, J.-G. Effect of Various Amendments on Heavy Mineral Oil Bioremediation and Soil Microbial Activity. Bioresour. Technol. 2008, 99, 2578-2587. [CrossRef] [PubMed]

15. Xiang, S.-R.; Doyle, A.; Holden, P.A.; Schimel, J.P. Drying and Rewetting Effects on C and N Mineralization and Microbial Activity in Surface and Subsurface California Grassland Soils. Soil Biol. Biochem. 2008, 40, 2281-2289. [CrossRef]

16. Young, I.; Ritz, K. Tillage, Habitat Space Andfunction of Soil Microbes. Soil Tillage 2000, 53, 201-213. [CrossRef]

17. Brzezińska, M. Aktywność Biologiczna Oraz Procesy Jej Towarzyszące w Glebach Organicznych Nawadnianych Oczyszczonymi Ściekami Miejskimi (Badania Polowe i Mode- Lowe). Acta Agrophys. 2006, 2, 131.

18. Mendes, R.; Garbeva, P.; Raaijmakers, J.M. The Rhizosphere Microbiome: Significance of Plant Beneficial, Plant Pathogenic, and Human Pathogenic Microorganisms. FEMS Microbiol. Rev. 2013, 37, 634-663. [CrossRef] [PubMed] 
19. Finlay, B.J.; Esteban, G.F. Oxygen Sensing Drives Predictable Migrations in a Microbial Community. Environ. Microbiol. 2009, 11, 81-85. [CrossRef]

20. Gajda, A.M.; Czyż, E.A.; Ukalska-Jaruga, A. Comparison of the Effects of Different Crop Production Systems on Soil PhysicoChemical Properties and Microbial Activity under Winter Wheat. Agronomy 2020, 10, 1130. [CrossRef]

21. Gajda, A.M.; Czyż, E.A.; Klimkowicz-Pawlas, A. Effects of Different Tillage Intensities on Physicochemical and Microbial Properties of a Eutric Fluvisol Soil. Agronomy 2021, 11, 1497. [CrossRef]

22. Pett-Ridge, J.; Firestone, M.K. Redox Fluctuationstructures Microbial Communities in a Wet Tropical Soil. Appl. Environ. Microbiol. 2005, 71, 6998-7007. [CrossRef]

23. Standing, D.; Killham, K. The Soil Environment. In Modern Soil Microbiology; Van Elsas, J.D., Jansson, J.K., Trevors, J.T., Eds.; CRC Press: New York, NY, USA, 2007; pp. 1-22.

24. Dance, A. Soil Ecology: What Lies Beneath. Nature 2008, 455, 724-725. [CrossRef]

25. Song, Y.N.; Zhang, F.S.; Marschner, P.; Fan, F.L.; Gao, H.M.; Bao, X.G.; Sun, J.H.; Li, L. Effect of Intercropping on Crop Yield and Chemical and Microbiological Properties in Rhizosphere of Wheat (Triticum aestivum L.), Maize (Zea mays L.), and Faba Bean (Vicia faba L.). Biol. Fertil. Soils 2007, 43, 565-574. [CrossRef]

26. Mauchline, T.H.; Malone, J.G. Life in Earth-the Root Microbiome to the Rescue? Curr. Curr. Opin. Microbiol. 2017, 37, 23-28. [CrossRef] [PubMed]

27. Andreasen, T.; Nielsen, J.T.; Voriskova, J.; Heise, J.; Rønn, R.; Kjøller, R.; Jacobsen, C.S. Wood Ash Induced PH Changes Strongly Affect Soil Bacterial Numbers and Community Composition. Front. Microbiol. 2017, 8, 1400. [CrossRef] [PubMed]

28. Bulgarelli, D.; Schlaeppi, K.; Spaepen, S.; Ver Loren van Themaat, E.; Schulze-Lefert, P. Structure and Functions of the Bacterial Microbiota of Plants. Annu. Rev. Plant Biol. 2013, 64, 807-838. [CrossRef] [PubMed]

29. Zimmermann, S.; Frey, B. Soil Respiration and Microbial Properties in an Acid Forest Soil: Effects of Wood Ash. Soil Biol. Biochem. 2002, 34, 1727-1737. [CrossRef]

30. Björk, R.G.; Ernfors, M.; Sikström, U.; Nilsson, M.B.; Andersson, M.X.; Rütting, T.; Klemedtsson, L. Contrasting Effects of Wood Ash Application on Microbial Community Structure, Biomass and Processes in Drained Forested Peatlands: Wood Ash Effects on Drained Forested Peatlands. FEMS Microbiol. Ecol. 2010, 73, 550-562. [CrossRef]

31. Saarsalmi, A.; Smolander, A.; Kukkola, M.; Arola, M. Effect of Wood Ash and Nitrogen Fertilization on Soil Chemical Properties, Soil Microbial Processes, and Stand Growth in Two Coniferous Stands in Finland. Plant Soil 2010, 331, 329-340. [CrossRef]

32. Moilanen, M.; Silfverberg, K.; Hokkanen, T.J. Effects of Wood-Ash on the Tree Growth, Vegetation and Substrate Quality of a Drained Mire: A Case Study. For. Ecol. Manag. 2002, 171, 321-338. [CrossRef]

33. Bååth, E.; Arnebrant, K. Growth Rate and Response of Bacterial Communities to pH in Limed and Ash Treated Forest Soils. Soil Biol. Biochem. 1994, 26, 995-1001. [CrossRef]

34. Fritze, H.; Perkiömäki, J.; Saarela, U.; Katainen, R.; Kim, T.P.; Karp, M.; Haimi, J.; Romantschuk, M. Effect of Cd-Containing Wood Ash on the Microflora of Coniferous Forest Humus. FEMS Microbiol. Ecol. 2000, 32, 43-51. [CrossRef]

35. Ditzler, C.; Scheffe, K.; Monger, H.C.; Soil Science Division Staff. Soil Survey Manual; USDA Handbook 18; Government Printing Office: Washington, DC, USA, 2017; p. 603.

36. Stanek-Tarkowska, J.; Szostek, M.; Rybak, M. Effect of Different Doses of Ash from Biomass Combustion on the Development of Diatom Assemblages on Podzolic Soil under Oilseed Rape Cultivation. Agronomy 2021, 11, 2422. [CrossRef]

37. Cao, H.; Chen, R.; Wang, L.; Jiang, L.; Yang, F.; Zheng, S.; Wang, G.; Lin, X. Soil pH, Total Phosphorus, Climate and Distance Are the Major Factors Influencing Microbial Activity at a Regional Spatial Scale. Sci. Rep. 2016, 6, 25815. [CrossRef]

38. Jala, S.; Goyal, D. Fly Ash as a Soil Ameliorant for Improving Crop Production-A Review. Bioresour. Technol. 2006, 97, 1136-1147. [CrossRef]

39. Pandey, V.C.; Singh, N. Impact of Fly Ash Incorporation in Soil Systems. Agric. Ecosyst. Environ. 2010, 136, 16-27. [CrossRef]

40. Marschner, C.P.H.; Yang, R.; Lieberei, D.E. Crowley Soil and Plant Specific Effects on Bacterial Community Composition in the Rhizosphere Soil Biol. Biol. Biochem. 2001, 33, 1437-1445. [CrossRef]

41. Girvan, M.S.; Bullimore, J.; Pretty, J.N.; Osborn, A.M.; Ball, A.S. Soil Type Is the Primary Determinant of the Composition of the Total and Active Bacterial Communities in Arable Soils. Appl. Environ. Microbiol. 2003, 69, 1800-1809. [CrossRef]

42. Miethling, R.; Wieland, G.; Backhaus, H.; Tebbe, C.C. Variation of Microbial Rhizosphere Communities in Response to Crop Species, Soil Origin, and Inoculation with Sinorhizobium meliloti L33. Microb. Ecol. 2000, 40, 43-56. [CrossRef] [PubMed]

43. Strejcek, M.; Smrhova, T.; Junkova, P.; Uhlik, O. Whole-Cell MALDI-TOF MS versus 16S RRNA Gene Analysis for Identification and Dereplication of Recurrent Bacterial Isolates. Front. Microbiol. 2018, 9, 1294. [CrossRef] [PubMed]

44. Borowik, A.; Wyszkowska, J. Soil Moisture as a Factor Affecting the Microbiological and Biochemical Activity of Soil. Plant Soil Environ. 2016, 62, 250-255. [CrossRef]

45. Perkiömäki, J.; Fritze, H. Does Simulated Acid Rain Increase the Leaching of Cadmium from Wood Ash to Toxic Levels to Coniferous Forest Humus Microbes? FEMS Microbiol. Ecol. 2003, 44, 27-33. [CrossRef] [PubMed]

46. Aronsson, K.A.; Ekelund, N.G.A. Biological Effects of Wood Ash Application to Forest and Aquatic Ecosystems. J. Environ. Qual. 2004, 33, 1595-1605. [CrossRef]

47. Iovieno, P.; Bååth, E. Effect of Drying and Rewetting on Bacterial Growth Rates in Soil: Rewetting and Bacterial Growth in Soil. FEMS Microbiol. Ecol. 2008, 65, 400-407. [CrossRef] 
48. Demeyer, A.; Voundi Nkana, J.C.; Verloo, M.G. Characteristics of Wood Ash and Influence on Soil Properties and Nutrient Uptake: An Overview. Bioresour. Technol. 2001, 77, 287-295. [CrossRef]

49. Dutta, S.; Podile, A.R. Plant Growth Promoting Rhizobacteria (PGPR): The Bugs to Debug the Root Zone. Crit. Rev. Microbiol. 2010, 36, 232-244. [CrossRef]

50. Mayak, S.; Tirosh, T.; Glick, B.R. Effect of Wild-Type and Mutant Plant Growth-Promoting Rhizobacteria on the Rooting of Mung Bean Cuttings. J. Plant Growth Regul. 1999, 18, 49-53. [CrossRef]

51. Glick, B.R. The Enhancement of Plant Growth by Free-Living Bacteria. Can. J. Microbiol. 1995, 41, 109-117. [CrossRef]

52. Babalola, O.O. Beneficial Bacteria of Agricultural Importance. Biotechnol. Lett. 2010, 32, 1559-1570. [CrossRef]

53. Vega-Celedón, P.; Bravo, G.; Velásquez, A.; Cid, F.P.; Valenzuela, M.; Ramírez, I.; Vasconez, I.-N.; Álvarez, I.; Jorquera, M.A.; Seeger, M. Microbial Diversity of Psychrotolerant Bacteria Isolated from Wild Flora of Andes Mountains and Patagonia of Chile towards the Selection of Plant Growth-Promoting Bacterial Consortia to Alleviate Cold Stress in Plants. Microorganisms 2021, 9, 538. [CrossRef]

54. Lugtenberg, B.; Kamilova, F. Plant-Growth-Promoting Rhizobacteria. Annu. Rev. Microbiol. 2009, 63, 541-556. [CrossRef]

55. Pathma, J.; Kennedy, R.K.; Sakthivel, N. Mechanisms of Fluorescent Pseudomonads That Mediate Biological Control of Phytopathogens and Plant Growth Promotion of Crop Plants. In Bacteria in Agrobiology: Plant Growth Responses; Maheshwari, D.K., Ed.; Springer: Berlin/Heidelberg, Germany, 2011.

56. Jain, R.; Pandey, A. A Phenazine-1-Carboxylic Acid Producing Polyextremophilic Pseudomonas chlororaphis (MCC2693) Strain, Isolated from Mountain Ecosystem, Possesses Biocontrol and Plant Growth Promotion Abilities. Microbiol. Res. 2016, $190,63-71$. [CrossRef]

57. Kumar, A.; Meena, R.; Meena, V.S.; Bisht, J.K.; Pattanayak, A. Towards the Stress Management and Environmental Sustainability. J. Clean. Prod. 2016, 137, 821-822. [CrossRef]

58. Yasin, M.; Munir, I.; Faisal, M. Can Bacillus spp. enhance K+ uptake in crop species. In Potassium Solubilizing Microorganisms for Sustainable Agriculture; Meena, V.S., Maurya, B.R., Verma, J.P., Meena, R.S., Eds.; Springer: Delhi, India, 2016; pp. 163-170. [CrossRef]

59. Srivastava, R. Antifungal Activity of P. fluorescens against Different Plant Pathogenic Fungi. EJEAFChe 2008, 7, $2789-2796$.

60. Davies, P.J. Plant Hormones: Biosynthesis, Signal Transduction, Action! Springer: Berlin/Heidelberg, Germany, 2004.

61. Ligon, J.M.; Hill, D.S.; Hammer, P.E.; Torkewitz, N.R.; Hofmann, D.; Kempf, H.-J.; van Pée, K.-H. Natural Products with Antifungal Activity from Pseudomonas Biocontrol Bacteria. Pest Manag. Sci. 2000, 56, 688-695. [CrossRef]

62. Raaijmakers, J.M.; Vlami, M.; de Souza, J.T. Antibiotic Production by Bacterial Biocontrol Agents. Antonie Van Leeuwenhoek 2002, 81, 537-547. [CrossRef] [PubMed]

63. Radhakrishnan, R.; Hashem, A.; Abd_Allah, E. Bacillus: A Biological Tool for Crop Improvement through Bio-Molecular Changes in Adverse Environments. Front. Physiol. 2017, 8, 667. [CrossRef] [PubMed]

64. Glick, W.H.; Miller, C.C. Cardinal Making a Life in the Field of Organization Science. J. Organ. Behav. 2007, 28, 817-835. [CrossRef]

65. Busse, H.-J. Review of the Taxonomy of the Genus Arthrobacter, Emendation of the Genus Arthrobacter sensu lato, Proposal to Reclassify Selected Species of the Genus Arthrobacter in the Novel Genera Glutamicibacter gen. nov., Paeniglutamicibacter gen. nov., Pseudoglutamicibacter gen. nov., Paenarthrobacter gen. nov. and Pseudarthrobacter gen. nov., and Emended Description of Arthrobacter roseus. Int. J. Syst. Evol. Microbiol. 2016, 66, 9-37. [CrossRef]

66. Roy, P.; Kumar, A. Arthrobacter. In Beneficial Microbes in Agro-Ecology; Elsevier: Amsterdam, The Netherlands, $2020 ;$ pp. 3-14.

67. Krishnan, R.; Menon, R.R.; Tanaka, N.; Busse, H.-J.; Krishnamurthi, S.; Rameshkumar, N. Arthrobacter pokkalii sp nov, a Novel Plant Associated Actinobacterium with Plant Beneficial Properties, Isolated from Saline Tolerant Pokkali Rice, Kerala, India. PLOS ONE 2016, 11, e0150322. [CrossRef]

68. Li, Q.; Li, Y.; Zhu, X.; Cai, B. Isolation and Characterization of Atrazine Degrading Arthrobacter sp. AD26 and Use of This Strain in Bioremediation of Contaminated Soil. J. Environ. Sci. 2008, 20, 1226-1230. [CrossRef]

69. Wang, Q.; Xie, S. Isolation and Characterization of a High-Efficiency Soil Atrazine-Degrading Arthrobacter sp. Strain. Int. Biodeterior. Biodegrad. 2012, 71, 61-66. [CrossRef]

70. Xie, S.; Wan, R.; Wang, Z.; Wang, Q. Atrazine Biodegradation by Arthrobacter Strain DAT1: Effect of Glucose Supplementation and Change of the Soil Microbial Community. Environ. Sci. Pollut. Res. Int. 2013, 20, 4078-4084. [CrossRef]

71. Parag, A.; Kanekar, P.P.; Dhakephalkar, P.K. Isolation and Characterization of Arthrobacter sp. Strain MCM B-436, an AtrazineDegrading Bacterium, from Rhizospheric Soil. Int. Biodeterior. Biodegrad. 2007, 60, 273-278.

72. Guo, Q.; Zhang, J.; Wan, R.; Xie, S. Impacts of Carbon Sources on Simazine Biodegradation by Arthrobacter Strain SD3-25 in Liquid Culture and Soil Microcosm. Int. Biodeterior. Biodegrad. 2014, 89, 1-6. [CrossRef]

73. Xiao, W.; Ye, X.; Yang, X.; Zhu, Z.; Sun, C.; Zhang, Q.; Xu, P. Isolation and Characterization of Chromium (VI)-Reducing Bacillus sp. FY1 and Arthrobacter sp. WZ2 and Their Bioremediation Potential. Bioremed. J. 2017, 21, 100-108. [CrossRef]

74. Singer, A.C.; Gilbert, E.S.; Luepromchai, E.; Crowley, D.E. Bioremediation of Polychlorinated Biphenylcontaminated Soil Using Carvone and Surfactant-Grown Bacteria. Appl. Microbiol. Biotechnol. 2000, 54, 838-843. [CrossRef] [PubMed]

75. Gilbert, E.S.; Crowley, D.E. Plant Compounds That Induce Polychlorinated Biphenyl Biodegradation by Arthrobacter sp. Strain B1B. Appl. Environ. Microbiol. 1997, 63, 1933-1938. [CrossRef]

76. Joshi, M.N.; Pandit, A.S.; Sharma, A.; Pandya, R.V.; Desai, S.M.; Saxena, A.K.; Bagatharia, S.B. Draft Genome Sequence of Arthrobacter crystallopoietes Strain BAB-32, Revealing Genes for Bioremediation. Genome Announc. 2013, 1, e00452-13. [CrossRef] 
77. Murugappan, R.M.; Benazir-Begun, S.; Usha, C.; Lok-Kirubahar, S.; Karthikeyan, M. Growth Promoting and Probiotic Potential of the Endophytic Bacterium Rhodococcus Globerulus Colonizing the Medicinal Plant Plectranthus amboinicus (Lour.) Spreng. Int. J. Curr. Res. Rev. 2017, 9, 7-13.

78. McLeod, M.P.; Warren, R.L.; Hsiao, W.W.L.; Araki, N.; Myhre, M.; Fernandes, C.; Miyazawa, D.; Wong, W.; Lillquist, A.L.; Wang, D.; et al. The Complete Genome of Rhodococcus sp. RHA1 Provides Insights into a Catabolic Powerhouse. Proc. Natl. Acad. Sci. USA 2006, 103, 15582-15587. [CrossRef] [PubMed] 